\title{
USE OF DEVELOPMENT DATA TO ESTIMATE COLONIZATION TIME OF THE MYIASIS-CAUSING \\ FLY, chrysomya bezziana \\ (DIPTERA: CALLIPHORIDAE) \\ COLLECTED FROM HUMAN WOUNDS
}

\begin{abstract}
Bambaradeniya Y.T.B. ${ }^{1}$, Karunarathne W.A.I.P. ${ }^{1}$, Goonerathne I. ${ }^{2}$, Kotakadeniya R.B. ${ }^{3}$, Tomberlin J.K. ${ }^{4}$

${ }^{1}$ Department of Zoology, Faculty of Science, ${ }^{2}$ Department of Forensic Medicine, ${ }^{3}$ Department of Surgery, Faculty of Medicine, University of Peradeniya, Sri Lanka \& ${ }^{4}$ Department of Entomology, Texas A \& M University, College Station,
\end{abstract}

Texas, USA

\section{ABSTRACT}

Forensic entomological techniques are highly accepted for forensic investigations all over the world, especially to estimate the time of colonization (TOC) as related to the postmortem interval (PMI) of human or other vertebrate remains as well as with cases of neglect or abuse. Here, the accumulated degree days (ADD) method was used to calculate the TOC as related to three cases of myiasis associated with individuals admitted to the teaching hospital, Peradeniya during 2016. Chrysomya bezziana was recorded as the responsible species for all three cases. Chrysomya bezziana is an obligatory myiasis-causing fly species commonly infesting human and farm animals mainly in tropical and subtropical countries. According to the present study, time of colonization of wounds by $C$. bezziana in these three cases ranged from two to six days. Accordingly, the present paper highlights the lack of information to apply such forensic entomology investigations and the future steps to be taken to improve this field in Sri Lanka. In the future, forensic medical and judiciary authorities in the country can incorporate this technique to pursue legal cases on verification of the malpractices of caregivers of wound patients in the professional and personal environment, based on the time scale calculated from above method.

Key words: Forensic entomology, time of colonization, accumulated degree day, myiasis, Chrysomya bezziana

Corresponding author: inokap@pdn.ac.lk

\section{INTRODUCTION}

Forensic entomology is the application of arthropod-related material as evidence in criminal investigations ${ }^{1}$. Entomological evidence can be used to resolve three major questions. Such material can be used to determine when, how and where a particular crime scene was committed ${ }^{2}$.

Flies (Diptera) are the most common group of insects used as evidence in forensic investigations $^{3}$. In some cases, immature flies are present in wounds of living vertebrates. These events are referred to as myiasis ${ }^{4}$. Myiasis is considered the world's fourth most common travel-associated skin disease after cutaneous larva migrans, pyodermas and pruritic arthropod-reactive dermatitis $^{5}$. Even though myiasis has been 
reported globally, such events most commonly occur in tropical and subtropical countries $^{5}$. Typically myiasis associated larvae feed on the host's living or dead tissue, liquid body substance, or on ingested foods $^{6}$. Based on the host-larval relationship, myiasis is classified into three major groups, 1) obligatory, 2) facultative, and 3) accidental ${ }^{7}$. Larvae causing obligatory myiasis infest live tissues where as facultative larvae consume dead tissue. Accidental myiasis occurs when chance ingestion of fly eggs or larvae that survive in the gastro intestinal tract ${ }^{6}$. Emphasizing the infestation location, myiasis can be cutaneous, oral, nasal or gastrointestinal. Cutaneous myiasis is the most commonly encountered clinical form of the disorder and further can be classified into three groups: (1) furuncular, (2) creeping (migratory), and (3) wound (traumatic) ${ }^{8}$.

Diptera is one of the largest insect orders, with approximately 150,000 species in 150 families, and 10,000 genera ${ }^{9}$. Several fly species cause myiasis in humans. Examples include, but are not limited to, the primary screwworm Cochliomyia hominivorax Coquerel (Diptera: Calliphoridae) in the New World, Chrysomya bezziana Villeneuve (Diptera:Calliphoridae), Chrysomya megacephala Fabricius (Diptera: Calliphoridae), Wohlfahrtia magnifica Schiner (Diptera: Sarcophagidae) in the Old World ${ }^{10}$.Chrysomya bezziana is an obligate parasite, which causes myiasis in a wide range of vertebrates including livestock, domestic pets, and humans ${ }^{7}$. This species occurs throughout much of tropical and subtropical Africa, the Indian subcontinent and Southeast Asia from southern China to New Guinea ${ }^{11}$.

Accumulated Degree Days/Hours $(\mathrm{ADD} / \mathrm{ADH})$ are used to calculate TOC of decomposing remains by insects ${ }^{12}$. Poikilothermic creatures, such as insects, need a certain amount of energy to develop from one point of their life cycle to another. This growth is proportionate to the energy amount provided by surrounding thermal conditions. Therefore theoretically, the development of a fly from egg to adult can be predicted based on the temperature conditions experienced. Lower and uppertemperature thresholds also bind insect development. Immature insects exposed to temperatures outside of this range experience retarded growth or death ${ }^{13}$. Based on data generated through development studies of these insects, entomologists can estimate the TOC of human or animals by these insects. The present paper discusses the application of ADD/ADH to estimate TOC of myiasiscausing larvae using already available development data set for the myiasiscausing fly species.

\section{METHODOLOGY}

Three patients (Table 01) diagnosed with cutaneous myiasis were admitted to the surgery ward, teaching hospital, Peradeniya from February to April 2016. Larval samples were collected from each patient on the day of their admission. The larvae were removed from the wounds of each patient and transferred into separate vials $(7 \mathrm{ml}$ bijou bottles) containing $3 \mathrm{ml}$ saline as a means to keep them alive. Larvae were brought to the Entomology laboratory, the University of Peradeniya for assessment. Two to three larvae were preserved in $70 \%$ ethanol and the remaining were placed on a $50 \mathrm{~g}$ of piece of fish inside a petri dish, which was then stored in an uncontaminated insect-rearing jar (1L) containing saw dust at a depth of $1.25 \mathrm{~cm}$ and stored under laboratory conditions. This material served as pupation site for the post-feeding larvae under room conditions. The mouth of the jar was covered with cloth mesh to prevent adult flies from escaping and jars were placed on a shelf under ambient temperature. Emerged flies were killed using ethyl acetate and curated using standard entomological techniques ${ }^{14}$. Preserved larvae and emergent adults were identified using identification keys ${ }^{15}$. 
Stage of development was recorded for each larva preserved from each case. ADD values for each identified life stage were calculated using the following equation ${ }^{16}$ :

ADD (Accumulated Degree Days) = Time is taken to attain each life stage (days) $X$ (surrounding temperature* - lower threshold temperature of the species)

(*This can be environment/ experimental temperature or human body temperature)

To estimate the colonization time for each sample, initially, ADD values were calculated for development data obtained from a previously published laboratory study (Spradbery, 2002) ${ }^{17}$.For this study, the larval development temperature was considered $37^{\circ} \mathrm{C}$ as they were collected from human wounds. The lower threshold temperature for the fly species was considered $10^{\circ} \mathrm{C}^{16}$. These calculated ADD values for each development stage corresponded to the standard energy amount needed to attain each stage respectively.

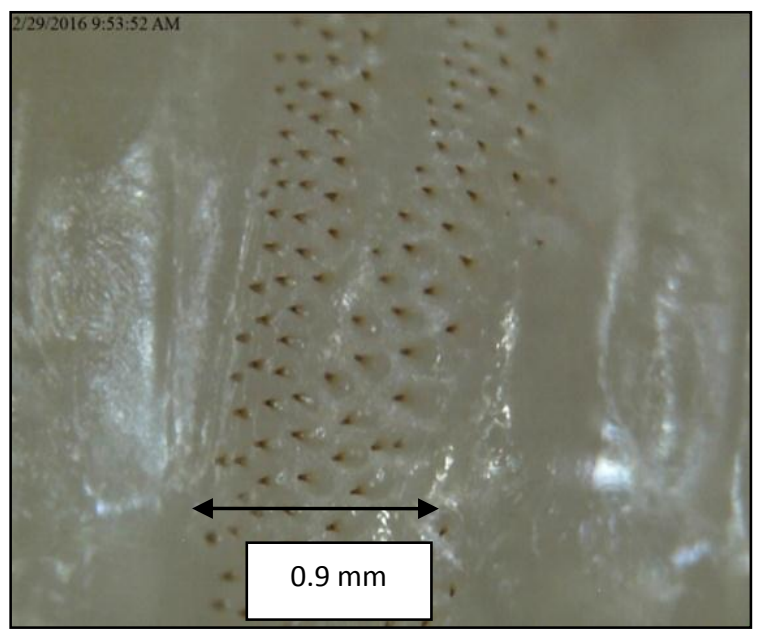

Figure 1: Heavy bands of dark, robust, thorn-like spines

\section{RESULTS}

\section{Species Identification}

Larval samples were collected from three patients admitted to the Peradeniya Teaching Hospital during a period of three months in 2016. Larvae in all samples were identified as C.bazziana .C.bazziana larvae are easily distinguished from related species by the presence of several prominent characters such as pinkish coloration of the body, heavy bands of dark, robust, thornlike spines (Fig. 01), 4-6 lightly sclerotized (pale brown) papillae or branches in anterior spiracles (Fig. 02), heavily sclerotized incomplete peritreme in dark brown to blackish posterior spiracle and with 3 slitlike spiracular openings at approximately $45^{\circ}$ to the horizontal plane ${ }^{15}$ (Fig. 03). The adult flies of $C$. bezziana were identified using characters such as metallic blue, bluish purple or blue/green body color with predominantly orange colored heads and burgundy-coloured eyes ${ }^{15}$ (Fig. 04).

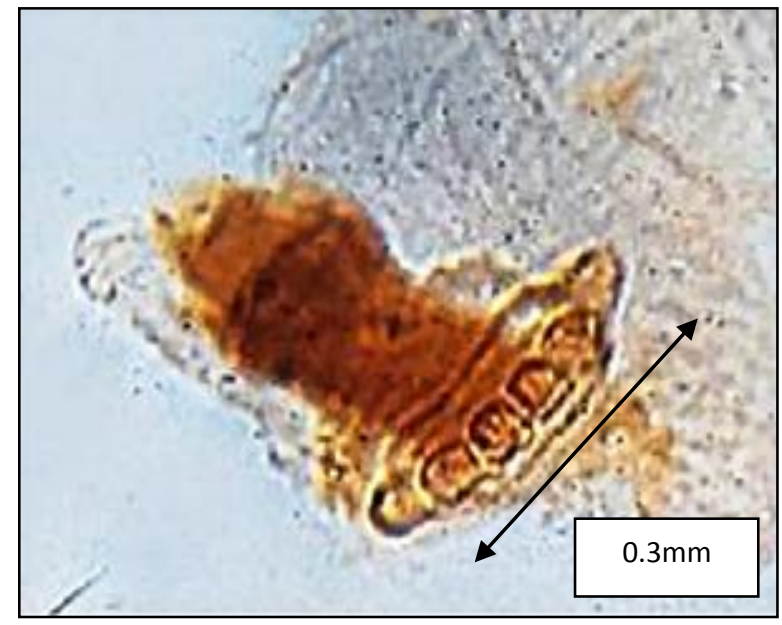

Figure 2: Six lightly sclerotized (pale brown) papillae or branches in anterior spiracles 


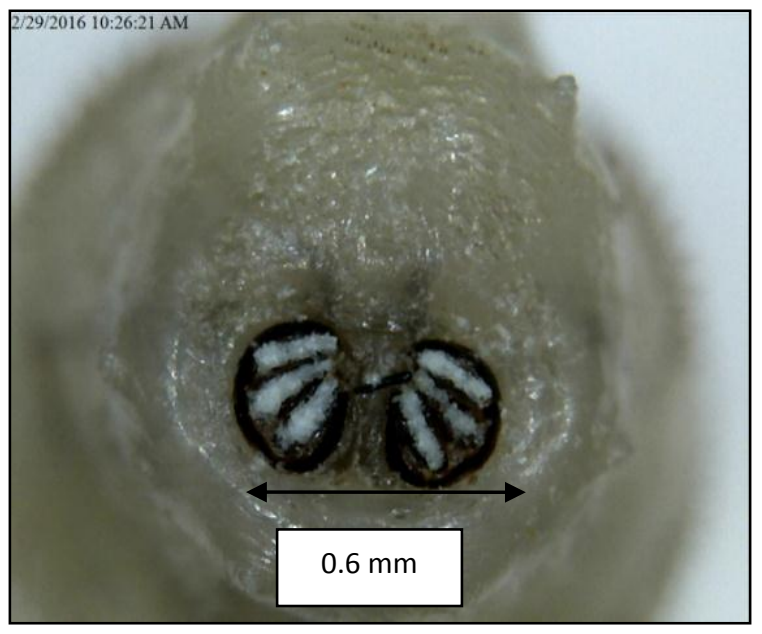

Figure 3: Heavily sclerotized incomplete peritreme in dark brown to blackish posterior spiracle and with 3 slit-like spiracular openings

\section{CASE DETAILS}

\section{Case No. -01}

Four live larvae were collected from a 76year-old male diabetic patient on 29/02/ 2016 at $09.00 \mathrm{~h}$ at the Teaching Hospital, Peradeniya. Clinical examination revealed the presence of the larvae infesting a wound in the right heel of the patient. In the laboratory, two larvae from the total were preserved and the remaining two were reared to get the adults. The larvae were $3^{\text {rd }}$ instarat the time of collection (Table 01).

Case No. -02

Two live larvae were collected from a 30year-old male patient on 18/03/2016 at $12.00 \mathrm{~h}$ at the Teaching Hospital, Peradeniya. According to the clinical examination, both legs of the patient had severe wounds with the right heel infested with larvae.

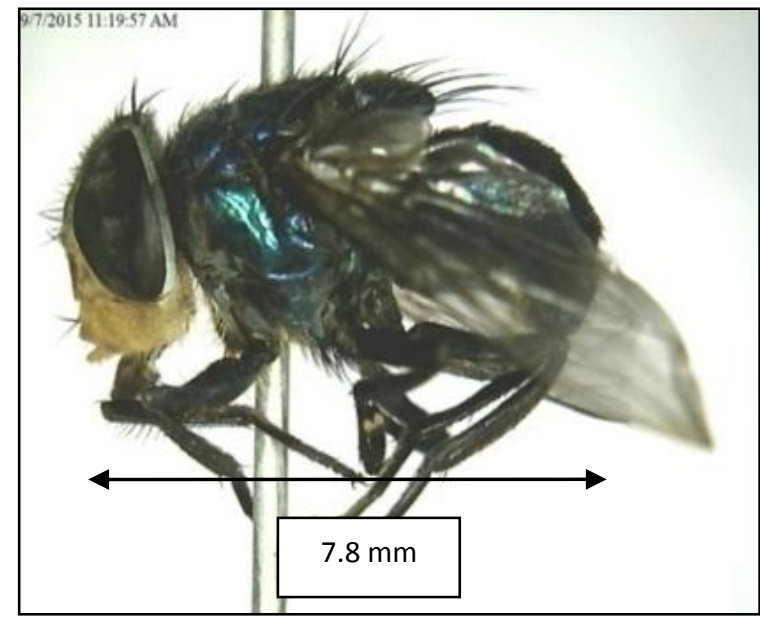

Figure 4: Blue/green body color of adult $C$. bezziana fly
Patient sensed a burning type irritation from the wound five days prior to admission to the hospital. One larva was preserved while the others were reared to the adult stage. The preserved larva was in the $2^{\text {nd }}$ instar stage (Table 01).

\section{Case No. -03}

Two live larvae were collected from a 65year-old female diabetic patient on $19 / 04 / 2016$ at $13.00 \mathrm{~h}$ at the Teaching Hospital, Peradeniya. A larval infested wound was located under the $2^{\text {nd }}$ left toe. The wound was first noticed by the patient three weeks prior to being admitted to the hospital. Collected larvae were in the $3{ }^{\text {rd }}$ instar stage (Table 01).

\begin{tabular}{|l|l|l|l|l|l|}
\hline \multicolumn{6}{|c|}{ Table 1: Background information of patients from which larvae were- collected. } \\
\hline $\begin{array}{l}\text { Case } \\
\text { No. }\end{array}$ & Sex & Age & $\begin{array}{l}\text { Wound } \\
\text { location }\end{array}$ & $\begin{array}{l}\text { Life stage of the fly } \\
\text { collected }\end{array}$ & $\begin{array}{l}\text { Number of larvae } \\
\text { collected }\end{array}$ \\
\hline 01 & M & 76 & Right heel & $3^{\text {rd }}$ instar & 4 \\
\hline 02 & M & 30 & Right heel & $2^{\text {nd }}$ instar & 2 \\
\hline 03 & F & 65 & $2^{\text {nd }}$ toe, left foot & $3^{\text {rd }}$ instar & 2 \\
\hline
\end{tabular}


Estimation of Colonization Time

\begin{tabular}{|l|l|l|l|l|l|}
\hline \multicolumn{6}{|c|}{ Table 2: ADD values for the experimental development time of C. } \\
\hline & $\begin{array}{l}\text { Thzianacalculatedusingdevelopment data given by Spradbery JP, 2001 } \\
\text { Minimum }\end{array}$ & $\begin{array}{l}\text { Developing } \\
\text { Temperature }\end{array}$ & $\begin{array}{l}\text { Development } \\
\text { Time (h) } \\
(\text { day= h/24) }\end{array}$ & Exp.DD & ADD \\
\hline & $10^{\circ} \mathrm{C}$ & $28^{\circ} \mathrm{C}$ & & & \\
\hline Egg & & & $20 \mathrm{~h}(0.83$ days $)$ & 14.9 & 14.9 \\
\hline $1^{\text {st }}$ Instar & & & $24 \mathrm{~h}(1$ day $)$ & 18 & 32.9 \\
\hline $2^{\text {nd }}$ Instar & & & $24 \mathrm{~h}(1$ day $)$ & 18 & 50.9 \\
\hline $3^{\text {rd }}$ Instar & & & $120 \mathrm{~h}$ (5days) & 90 & 140.9 \\
\hline Pupa & & & $168 \mathrm{~h}(7$ days $)$ & 126 & 266.9 \\
\hline Total ADD & & & & & 266.9 \\
\hline
\end{tabular}

The lower threshold temperature for the fly species was considered $10^{\circ} \mathrm{C}{ }^{16}$. This is because in many calliphorid related studies this temperature was the standard lower threshold temperature of larval growth.

\begin{tabular}{|c|c|c|c|}
\hline $\begin{array}{l}\text { Date prior to } \\
\text { infestation }\end{array}$ & $\begin{array}{ll}\text { Mean } & \text { body } \\
\text { Temperature } & \end{array}$ & DD & ADD \\
\hline 28/02/2016 & 37 & 27 & 27 \\
\hline 27/02/2016 & 37 & 27 & 54 \\
\hline 26/02/2016 & 37 & 27 & 81 \\
\hline 25/02/2016 & 37 & 27 & 108 \\
\hline $24 / 02 / 2016$ & 37 & 27 & 135 \\
\hline$* 23 / 02 / 2016$ & 37 & 27 & 162 \\
\hline $22 / 02 / 2016$ & 37 & 27 & 189 \\
\hline $21 / 02 / 2016$ & 37 & 27 & 216 \\
\hline
\end{tabular}

*- Day attains the $3^{\text {rdinstra larvae }}$ 
According to the above calculation, in case study 01 , eggs have been laid 6 days prior to removal of larvae (23/02/2016). In case 02, eggs have been laid two days prior to removal of larvae (16/03/2016). And, in case 03 , eggs have been laid 6 days prior to removal (13/04/2016).

\section{DISCUSSION}

Although this is not the first investigation to document $C$. bazziana infesting human hosts in Sri Lanka, it is the first to utilize entomological techniques to estimate the TOC of humans by this species. An extensive study carried out by Kumarasinghe et $\mathrm{al}^{18}$, in Colombo and Kaluthara district over 18 months, which was initiated in 1997, recorded 16 myiasis cases with 14 involving $C$. bazziana. Prior to the current study, other three $C$. bazziana infestations were only known from two incidents of nasal myiasis ${ }^{19}$ and one of cutaneous myiasis $^{20}$.

Risk factors leading to myiasis include poor personal hygienic practices, improper wound management and less concerning of good environmental hygiene ${ }^{19}$. The three patients in this study were from rural areas associated with low socioeconomic development.

Consequently, patients do not have proper access to health care professionals. The lack of resources possibly explains the poor wound care observed which could have led to ulceration and prolonged exposure to myiasis-causing flies. In this study, the infestation site associated with each patient was the foot. Kumarasinghe et al ${ }^{18}$ recorded 15 of 16 cases involving foot myiasis. They observed that this commonly occurred due to non-wearing of shoes by patients who came to hospitals from rural areas of the country.

In this study, an attempt was made to calculate the TOC by $C$. bezziana using ADD. Historically, this method is used to calculate the TOC associated with the $\mathrm{PMI}^{12}$.In Forensic entomology, two basic methods have been used to calculate the PMI namely temperature related methods and stage of succession ${ }^{12}$. ADD/ADH method and isomegalen/isomorphen diagram method are categorized under the temperature related methods which are the major techniques of calculating the TOC. The use of temperature-related methods is based on the hypothesized linear relationship between the temperature and development of flies ${ }^{12}$. ADD/ADH method was used here to identify the TOC of wounds by larvae, as it is the standard and most sophisticated technique used in many forensic cases to estimate the development rate of flies over a period of time ${ }^{21}$.

In this study, several assumptions were made. Typically with calculating ADD, ambient temperatures are used as the function of the rate of development. But in these cases, human body temperature was employed due to the host body serving as the primary source of heat for larval development. However, the impact of ambient temperature in conjunction with body-associated heat on the development of these insects is not known.

A second issue that there was no data published on the development of $C$. bazziana at this temperature. Therefore, the calculation was done using the available temperature $\left(28{ }^{\circ} \mathrm{C}\right)$ given by Spradbery ${ }^{17}$. As the rate of larval development very with varying temperatures, this may have affected the calculated ADD. Development studies done for blowflies (Diptera: Calliphoridae) show that the development times within species vary for a variety of species $^{22,23}$.

A third assumption was the data from Spradbery ${ }^{17}$ would be appropriate for application in the current study. The variation could be the result of a number of factors, such as experimental design, environment, and genetic variation. Tarone 
and Foran $^{22}$ determined that environment conditions greatly influenced the development of the blow fly Lucilia sericata Meigen (Diptera: Calliphoridae). Their findings demonstrate the need for multiple development data sets for each species of blowfly across geographic regions, as well as for a standardization of laboratoryrearing techniques ${ }^{24}$.

As this study establishes the method of recording development stages of forensically significant flies in Sri Lanka, in the future, forensic medical and judiciary authorities in the country can incorporate this technique to pursue legal cases on verification of the malpractices of caregivers of wound patients in the professional and personal environment, based on the time scale calculated from above method. The present study highlights the importance of identifying the forensically important fly species found in Sri Lanka and recording their development data in order to build up the field of forensic entomology in the country.

\section{ACKNOWLEDGMENT}

The authors are thankful to the National Research Council, Sri Lanka for providing financial support for this study (Grant No: 15- 084).

\section{REFERENCES}

1. Hall. RD. Perceptions and status of forensic entomology. In: Byrd. J.H, Castner J.L. Forensic Entomology: The utility of Arthropods in legal investigations. Florida: CRC press, 2001: 1-15.

2. Anderson GS. Succession on carrion and its relationship to determining time of death. In: Byrd JH, Castner JL (eds). Forensic entomology :the utility of arthropods in legal investigations. Florida: CRC press, 2001: 143-175.
3. Byrd JH, CastnerJL.Insects of forensic importance. In: Byrd JH, Castner JL (eds). Forensic entomology :the utility of arthropods in legal investigations. Florida: CRC press, 2001: 43- 73

4. Zumpt F. Myiasis in man and animals in the old world.A Textbook for Physicians, Veterinarians and Zoologists. London: Butter worths, 1965: 89- 102.

5. Caumes E, Carriere J, Guarmonpres G, Bricaire F, Danis M, Gentilini M.. Dermatoses associated with travel to tropical countries - a prospective study of the diagnosis and management of 269 patients presenting to a tropical disease unit. Clin. Infect. Dis, 1995: 20: 542-548.

6. Noutsis C, Millikan LE. Myiasis. Dermatol. Clin, 1994: 12:729-736

7. Hang LK, Lui TH. Myiasis of foot and leg caused by Chrysomyabezziana. The journal of foot and Ankle surgery.2014; 53: 88- 91.

8. Fransesconi F, Lupi O, Myiasis. Clinical Microbiology Reviews. 2012; pp 79- 105.

9. McAlpine JF. Morphology and terminology: adults. In Mc Alpine JF, et al. (ed), Manual of NearticDiptera. Canada: Agriculture Canada Research Branch, 1981: 27: 9-63

10. Hall M, Wall R. Myiasis of humans and domestic animals. AdvParasitol, 1995: $35: 257$

11. Sutherst RW, Spradbery JP, Maywald GF.The potential geographical distribution of the old world screw- warm fly, Chrysomyabezziana. Medical and VeterinaryEntomology. 1989; 3: 273- 280.

12. Amendt J, KretteK R, Zehner R. Forensicentomology. Naturwissenscnaften. 2004; 91: 51- 65

13. Gabre RM, Adham FK, Chi H. Life table of Chrysomyamegacephala (Fabricius) (Diptera: Calliphoridae). International Journal of Ecology. 2005; 27: 179- 183. 
14. Donald JB, Triplehorn CH, Johnson NF, An introduction to the study of insects. Harcourt Brace College Pub. 1992: 745771.

15. James MT. The Flies that Cause Myiasis in Man. Washington: United state government printing office, 1947.

16. Algalil FMA, Zambare SP. Effects of temperature on the development of Calliphorid fly of forensic importance Chrysomyamegacephala (Fabricius, 1794). Indian Journal of Applied Research. 2015; 5: 167- 769 .

17. Spradbery JP. A Manual for the Diagnosis of Screw- Warm Fly.Dep. of Agriculture, Fisheries \& Forestry- Australia, 2002.

18. Kumarasinghe SP, Karunaweera ND, Ihalamulla RI. A study of cutaneous myiasis in Sri Lanka.International Journal of Dermatology. 2000: 39 :689- 694.

19. Bayer HGA. Myiasis maligna of nose and ears in Ceylon: Recommendation of a new treatment. Archives of Otolaryngology. 1954: 1- pp 104- 107.
20. De silva NR, Madagedera D, et al. Wound myiasis due to Chrysomyabezziana: a case report. Kandy MedicalJournal. 1992: 1: 7576.

21. Costa O, Mello- patio C. Application of Forensic Entomology to estimate of the PMI in homicide investigations by the Rio de Janeiro police department in Brazil. Aggraval's Int. Journal of Forensic Medicine and Toxicology. 2004: 5: 41- 44.

22. Tarone A, Foran D. Components of developmental plasticity in a Michigan population of Luciliasericata(Diptera: Calliphoridae). Journal of Medical Entomology. 2006: 43 (5): 1023-1033.

23. Gallagher M, Sandhu S, Kimsey R. Variation in development time for geographically distinct populations of the common green bottle fly, Luciliasericata (Meigen). Journal of Forensic Science. 2010: 55: 438- 442 .

24. Boatright S, Tomberlin J.K. Effect of temperature and tissue type on the development of Cochiomyiamacellaria (Diptera: Calliphoridae). Journal of Medical Entomology. 2010: 47: 917- 23. 